\title{
ARTICLE
}

\section{Contemporary interspecific hybridization between Dracocephalum kotschyi and Dracocephalum oligadenium (Lamiaceae): Evidence from morphological, anatomical and molecular data}

\author{
Fahimeh Koohdar ${ }^{1, *}$, Farideh Attar ${ }^{2}$, Seyed Mehdi Talebi ${ }^{3}$, Masoud Sheidai ${ }^{1}$ \\ ${ }^{1}$ Faculty of Life Sciences \& Biotechnology, Shahid Beheshti University, Tehran, Iran \\ ${ }^{2}$ Central Herbarium of Tehran University, School of Biology, College of Science, University of Tehran, Tehran, Iran \\ ${ }^{3}$ Department of Biology, Faculty of Science, Arak University, Arak, Iran
}

\begin{abstract}
Dracocephalum is the second largest genus in the family Lamiaceae with about 186 species. These species are native in temperate regions of the Northern Hemisphere and occur in the territory of the extra-tropical Asia and Europe. Eight Dracocephalum species reported in Iran; these are mainly growing in the northern and central parts of the country belonging to the Irano-Turanian phytogeographical region. Dracocephalum kotschyi is an important medicinal plant in the country. At the same time, taxonomic position of Dracocephalum oligadenium is a challenging issue. In this work morphological, anatomical and Inter Simple Sequence Repeat (ISSR) markers were used to identify these species in Iran. MDS plot based on morphological and anatomical characters, furthermore, PCoA and MST plot based on ISSR data of species revealed hybridization between $D$. oligadenium and $D$. kotschyi.
\end{abstract}

Acta Biol Szeged 62(2):123-129 (2018)

\author{
KEY WORDS \\ anatomy \\ D. oligadenium \\ D. kotschyi \\ hybridization \\ ISSR \\ morphology \\ ARTICLE INFORMATION \\ Submitted \\ 1 October 2018 \\ Accepted \\ 5 November 2018 \\ *Corresponding author \\ E-mail:f_koohdar@yahoo.com
}

\section{Introduction}

The genus Dracocephalum L. also named dragonhead (Lamiaceae) contains about 186 species (Budantsev 1987, 1993; Kadereit 2004). Dracocephalum species are mostly perennial, rarely annual herbs growing in alpine and semi-dry regions. They grow mainly in temperate Asia, with a few species occurring in Europe and only one in North America (Brach and Song 2006). These species have medicinal values and are used in anti-hyperlipidemic, analgesic, antimicrobial, antioxidant, anticancer treatments (Sajjadi et al. 1998; Jahaniani et al. 2005; Sonboli et al. 2008; Zeng et al. 2010).

Budantsev (1987) divided Dracocephalum genus into three subgenera namely, Dracocephalum L., Fedtschenkiella (Kudr.) Schischk and Ruyschiana (Mill.) Briq. The subgenus Dracocephalum includes seven sections, the members of which have glabrous anthers and stamens.

Eight Dracocephalum species were reported in Flora Iranica (Rechinger 1982), while Jamzad (2012) reported 10 species in Flora of Iran. Five of these species are endemic to Iran.

The occurrence of $D$. oligadenium Bornm. \& Gauba in Iran is in dispute. Esfandiari (1985) reported the occurrence of both $D$. kotschyi Boiss. and D. oligadenium in the country, while Jamzad (2012) considered these two as synonyms and reported only the occurrence of D. kotschyi.

During our extensive field collection of Dracocephalum species in Iran, based on morphological features we encountered the presence of both Dracocephalum species. Therefore, the present study has been performed to differentiate these two presumed species by multiple approaches using morphological, anatomical and molecular data. Moreover, we found plants with intermediate morphological characters. Therefore, we also tried to reveal the hybrid nature of these plants by using multiple data sets.

\section{Materials and methods}

\section{Plant materials}

Plant materials (70 plant specimens) were collected from 7 geographical populations and used for morphological, anatomical, and ISSR molecular studies (Table 1). The voucher specimens are deposited in Herbarium of Shahid Beheshti University (HSBU; Tehran, Iran). 
Koohdar et al.

Table 1. Geographical locations of the studied populations.

\begin{tabular}{|c|c|c|c|c|c|c|}
\hline No & Province & Locality & Number of samples & Altitude (m) & Longitude & Latitude \\
\hline 1 & Mazandran & Rineh & 10 & 2026 & 3552 & 5210 \\
\hline 2 & Tehran & Fasham & 10 & 2217 & 3557 & 2133 \\
\hline 3 & Qazvin & Evan & 10 & 1796 & 3629 & 5026 \\
\hline 4 & Mazandran & Noor & 10 & 2043 & 3612 & 5148 \\
\hline 5 & Mazandran & Namarestagh & 10 & 2370 & 3603 & 5203 \\
\hline 6 & Qazvin & Niroogah & 10 & 1318 & 3617 & 5001 \\
\hline 7 & Gilan & Roodbar & 10 & 1473 & 3648 & 4922 \\
\hline
\end{tabular}

\section{Morphological and anatomical studies}

Altogether, 20 morphological characters and 26 anatomical characters were studied in collected plants (Table 2 and 3).

For anatomical studies, embedded materials were prepared as follows: the adult plants samples (leaves and stems) were excised and immediately fixed for 48 to 72 $\mathrm{h}$ in a mixture of formalin:acetic acid:ethanol (90\%) of 5\%:5\%:50\%, respectively, than stored at $4{ }^{\circ} \mathrm{C}$ until sectioning. Samples were dehydrated in a graded ethanol series and embedded. After preparation of free transverse hand sections of the lamina and stem, samples were washed with distilled water and placed in 5\% sodium hypochlorite solution for $20 \mathrm{~min}$ for clearing then gently rinsed with distilled water. The sections were stained with aqueous solution of methylene blue (1\%) and carmine and mounted on the slides using Canada balsam (Jensen 1962). Thin cut sections were studied under a microscope fitted with

Table 2. Morphological characteristics in the studied populations.

\begin{tabular}{ll}
\hline No. & Characters \\
\hline 1 & Habitat form \\
2 & Margin of stem leaves \\
3 & Plant height $(\mathrm{cm})$ \\
4 & Length of basal leaf $(\mathrm{mm})$ \\
5 & Width of basal leaf $(\mathrm{mm})$ \\
6 & Length of petiole in basal leaf $(\mathrm{mm})$ \\
7 & Length of stem leaf $(\mathrm{mm})$ \\
8 & Width of stem leaf $(\mathrm{mm})$ \\
9 & Length of petiole in stem leaf $(\mathrm{mm})$ \\
10 & Length of inflorescence leaf $(\mathrm{mm})$ \\
11 & Width of inflorescence leaf $(\mathrm{mm})$ \\
12 & Length of petiole in inflorescence leaf $(\mathrm{mm})$ \\
13 & Size of inflorescence leaf arista $(\mathrm{mm})$ \\
14 & Length of bracteole $(\mathrm{mm})$ \\
15 & Width of bracteole $(\mathrm{mm})$ \\
16 & Size of bract arista $(\mathrm{mm})$ \\
17 & Length of calyx $(\mathrm{mm})$ \\
18 & Length of corolla $(\mathrm{mm})$ \\
19 & Width of calyx (mm) \\
20 & Size of tooth in calyx $(\mathrm{mm})$ \\
\hline
\end{tabular}

digital camera. Anatomical characters of stem and leaf were summarized in Table 3.

Morphological and anatomical characters were first standardized (Mean $=0$; Variance $=1$ ) and used to establish Euclidean distance among pairs of taxa. For grouping of the plant specimens Multidimensional Scaling (MDS) and Principal Components Analysis (PCA) were used (Podani 2000). PAST version 2.17 (Hammer et al. 2012) was used for multivariate statistical analyses.

\section{DNA extraction and ISSR assay}

Fresh leaves were collected in each of the studied populations and dried in silica gel powder. The genomic DNA was extracted using cetyltrimethylammonium bromide (CTAB)-activated charcoal protocol (Sheidai et al. 2014). The extraction procedure was based on activated charcoal and polyvinylpyrrolidone (PVP) for binding of polyphenolics during extraction and on mild extraction and precipitation conditions promoting high-molecular weight DNA isolation without interfering contaminants.

Ten ISSR primers were used: (AGC) 5GT, (CA) 7GT, (AGC) 5GG, UBC810, (CA) 7AT, (GA) 9C, UBC807, UBC811, (GA) 9A and (GT) 7CA. These were commercialized by University of British Columbia (UBC).

Polymerase chain reactions (PCR) were performed in $25 \mu$ lvolumes containing $10 \mathrm{mM}$ Tris- $\mathrm{HCl}$ buffer $(\mathrm{pH} 8), 50$ $\mathrm{mM} \mathrm{KCl}, 1.5 \mathrm{mM} \mathrm{MgCl} 2,0.2 \mathrm{mM}$ of each dNTP (Bioron, Germany), $0.2 \mu \mathrm{M}$ of a single primer, $20 \mathrm{ng}$ genomic DNA and $3 \mathrm{U}$ of Taq DNA polymerase (Bioron, Germany).

The amplification reactions were performed in a thermal cycler (Techne, Germany) with the following program: $94^{\circ} \mathrm{C}$ for $5 \mathrm{~min}$, followed by 40 cycles at $94^{\circ} \mathrm{C}$ for $30 \mathrm{sec}, 57^{\circ} \mathrm{C}$ for $1 \mathrm{~min}$, and $72^{\circ} \mathrm{C}$ for $1 \mathrm{~min}$, followed by one final extension at $72^{\circ} \mathrm{C}$ for $7 \mathrm{~min}$. The amplification products were visualized by running on a $2 \%$ agarose gel, followed by ethidium bromide staining. The fragment size was estimated by using a $100 \mathrm{bp}$ molecular size ladder (Fermentas, Germany).

ISSR bands obtained (results not shown) were coded as binary characters (presence $=1$, absence $=0$ ). Grouping was done by Neighbor Joining (NJ) clustering, Neighbor 
Table 3. Anatomical characteristics in the studied populations.

\begin{tabular}{ll}
\hline No. & Characters \\
\hline 1 & Thickness of epidermis in stem $(\mu \mathrm{m})$ \\
2 & Thickness of collenchymas in stem $(\mu \mathrm{m})$ \\
3 & Thickness of parenchyma in stem $(\mu \mathrm{m})$ \\
4 & Thickness of sclerenchyma in stem $(\mu \mathrm{m})$ \\
5 & Thickness of upper phloem in stem $(\mu \mathrm{m})$ \\
6 & Thickness of xylem in stem $(\mu \mathrm{m})$ \\
7 & Thickness of lower phloem in stem $(\mu \mathrm{m})$ \\
8 & Thickness of pith in stem $(\mu \mathrm{m})$ \\
9 & Length of transects in stem $(\mu \mathrm{m})$ \\
10 & Width of transects in stem $(\mu \mathrm{m})$ \\
11 & Length of simple hair in stem $(\mu \mathrm{m})$ \\
12 & Length of glandular hair in stem $(\mu \mathrm{m})$ \\
13 & Number of layers of collenchymas in stem \\
14 & Number of layers of parenchyma in stem \\
15 & Number of layers of xylem in stem $(\mu \mathrm{m})$ \\
16 & Thickness of upper epidermis in leaf $(\mu \mathrm{m})$ \\
17 & Thickness of collenchymas in leaf $(\mu \mathrm{m})$ \\
18 & Thickness of parenchyma in leaf $(\mu \mathrm{m})$ \\
19 & Thickness of upper phloem in leaf $(\mu \mathrm{m})$ \\
20 & Thickness of xylem in leaf $(\mu \mathrm{m})$ \\
21 & Thickness of simple hair in leaf $(\mu \mathrm{m})$ \\
22 & Thickness of glandular hair in leaf $(\mu \mathrm{m})$ \\
23 & Number of layers of collenchymas in leaf \\
24 & Number of layers of parenchyma in leaf \\
25 & Number of layers of xylem in leaf \\
26 & Thickness of lower phloem in leaf $(\mu \mathrm{m})$ \\
\hline &
\end{tabular}

Net of ordination as well as PCA. They were performed after 100 times bootstrapping/permutations (Freeland et al. 2011; Huson and Bryant 2006).

Moreover, minimum spanning tree (MST) was per-

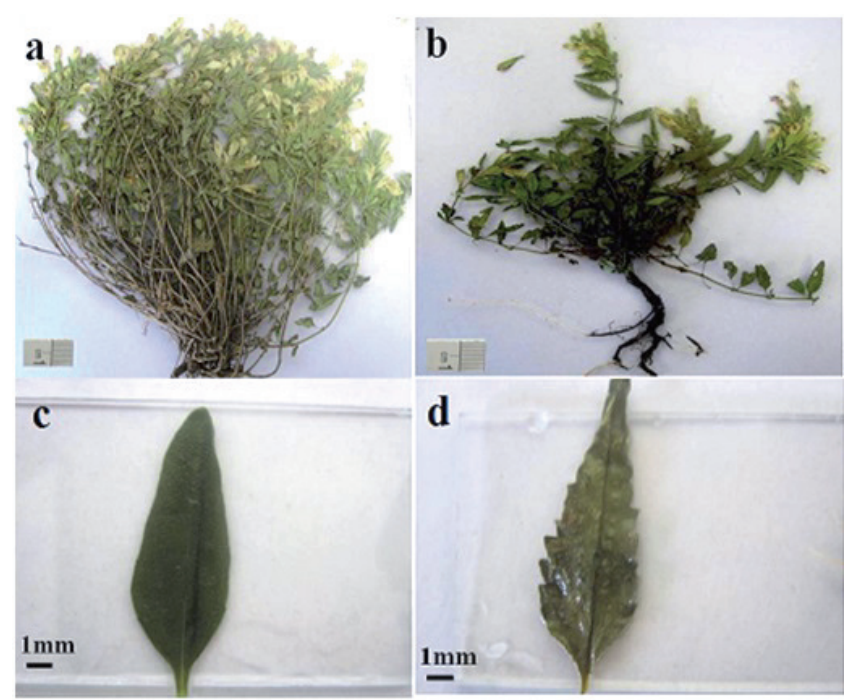

Figure 1. Habitat form and margin of stem leaves in D. oligadenium and D. kotschyi.

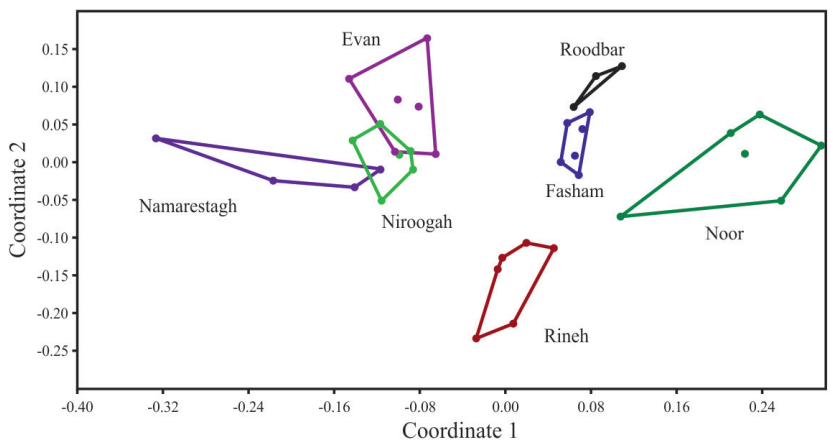

Figure 2. MDS plot of populations based on morphological characters.

formed to illustrate genetic affinity of the presumed hybrid plants. Data analyses were performed by using PAST ver. 2.17 (Hammer et al. 2012).

\section{Results}

\section{Morphometry}

Detailed morphological investigation of the collected $D$. oligadenium (Evan, Namarestagh and Niroogah populations) and D. kotschyi samples (Fasham, Roodbar and Noor populations) revealed that these species mainly differ in habitat form and margin of stem leaves (Fig. 1 and Table 4). D. oligadenium has cartridges habitat form, while $D$. kotschyi is cartridges-cushions. Similarly, the stem leaves in the first is teethed, while they are smooth in the second one. Moreover, the plant specimens in these two species were differentiated by MDS plot based on all the studied morphological features (Fig. 2; Table 5).

We collected plants with intermediate characters in Rhine population (10 plants). They had habitat form of $D$. oligadenium and the leaf margin of $D$. kotschyi. MDS plot (Fig. 2) based on morphological characters separated D. oligadenium populations (Evan, Nomarestaq and Niroogah) from D. kotschyi populations (Fasham, Roodbar and Noor), while plants of Rineh population were placed in an intermediate position between the two species and may be considered as potential hybrids.

Table 4. Results of qualitative morphological traits in populations studies.

\begin{tabular}{|c|c|c|}
\hline Species & Habitat form & Margin of stem leaves \\
\hline D. oligadenium & Cartridges & Teeth of the leaves very deep \\
\hline D. kotschyi & Cartridges-cushions & Teeth of the leaves not very deep \\
\hline
\end{tabular}


Table 5. Results of quantitative morphological traits in populations studies.

\begin{tabular}{|c|c|c|c|c|c|c|c|}
\hline \multirow[b]{2}{*}{ Characters } & \multicolumn{7}{|c|}{ Populations } \\
\hline & Rineh & Fasham & Evan & Noor & Namarestagh & Niroogah & Roodbar \\
\hline Plant height $(\mathrm{cm})$ & 18.1 & 20.3 & 24.8 & 20.3 & 21 & 17.3 & 21 \\
\hline Length of basal leaf (mm) & 6.2 & 8.3 & 10 & 9.1 & 8.3 & 7.3 & 10.7 \\
\hline Width of basal leaf (mm) & 4.3 & 5.8 & 6.8 & 5.8 & 5.5 & 4.7 & 8.3 \\
\hline Length of petiole in basal leaf $(\mathrm{mm})$ & 4.1 & 5.7 & 8.8 & 8.2 & 5.8 & 4.7 & 4.3 \\
\hline Length of stem leaf $(\mathrm{mm})$ & 13 & 18.1 & 19.5 & 17.8 & 13.8 & 17.2 & 17 \\
\hline Width of stem leaf $(\mathrm{mm})$ & 6.8 & 8 & 8 & 8 & 5.8 & 7.4 & 7.5 \\
\hline Length of petiole in stem leaf $(\mathrm{mm})$ & 3 & 3.3 & 3.7 & 5.2 & 2.8 & 3.5 & 2.7 \\
\hline Length of inflorescence leaf (mm) & 9.3 & 13.6 & 11.8 & 15.2 & 12 & 11.8 & 16 \\
\hline Width of inflorescence leaf (mm) & 4 & 4.3 & 4.8 & 7 & 4.8 & 4.4 & 6.7 \\
\hline Length of petiole in inflorescence leaf (mm) & 2.2 & 2.1 & 2.2 & 2.7 & 4.8 & 2 & 2 \\
\hline Size of inflorescence leaf arista $(\mathrm{mm})$ & 2.6 & 3 & 3.5 & 4.5 & 2.5 & 3.7 & 2 \\
\hline Length of bracteole $(\mathrm{mm})$ & 4.5 & 4.9 & 5.7 & 6.1 & 4.8 & 4.3 & 5 \\
\hline Width of bracteole $(\mathrm{mm})$ & 1.8 & 1.8 & 1.9 & 3.4 & 4.6 & 2.1 & 2.3 \\
\hline Size of bract arista (mm) & 2.5 & 3.3 & 3.2 & 4.4 & 3.5 & 3 & 2 \\
\hline Length of calyx (mm) & 16.2 & 14.8 & 16.2 & 14.3 & 13 & 14.7 & 15 \\
\hline Length of corolla (mm) & 26.8 & 28.4 & 24.7 & 25.8 & 19.5 & 22.8 & 27.3 \\
\hline Width of calyx $(\mathrm{mm})$ & 5.3 & 5 & 4.8 & 4.8 & 4.5 & 5.3 & 5 \\
\hline Size of tooth in calyx (mm) & 6.2 & 6.8 & 5.8 & 6.2 & 5 & 6.7 & 6 \\
\hline
\end{tabular}

\section{Anatomy}

Details of mean of anatomical characteristics in seven studied population are provided in Table 6. PCA analysis of anatomical features revealed that the first 3 PCA components comprise about $75 \%$ of total variance. PCA revealed that anatomical characters like the thickness of collenchyma, sclerenchyma, lower and upper phloem, and xylem, as well as width of transects are the most variable anatomical characters. These characters differentiate both the species studied as well as the "hybrid population" (Fig. 3).

In this study, the stems in the cross section have a square form with pronounced angles and are covered with a one-layered epidermis. Collenchyma is singlelayered among the angles but 8-11 layers of collenchyma are observed below the epidermis at the angles. Phloem and xylem were regular cylinders.

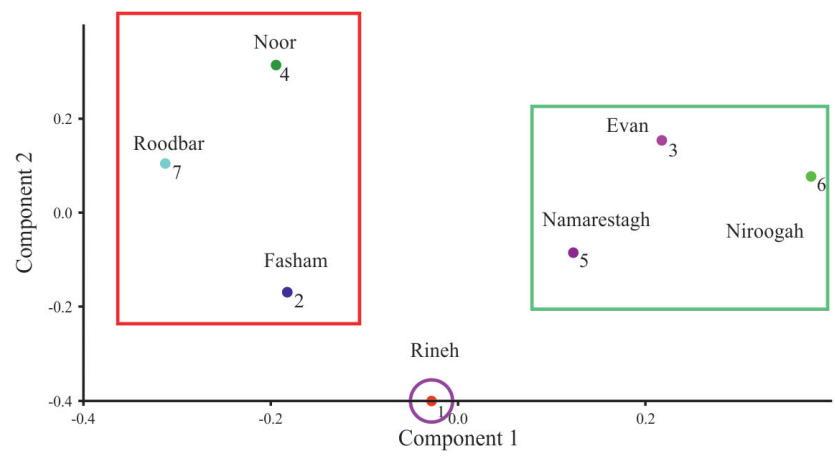

Figure 3. MDS plot of populations based on anatomical characters.
The highest thickness of parenchyma $(68.81 \mu \mathrm{m})$, sclerenchyma $(33.44 \mu \mathrm{m})$, lower phloem $(62.4 \mu \mathrm{m})$ and length of glandular hair $(46.51 \mu \mathrm{m})$ in stem was observed in Rineh population. These characters are attributes that diverge the population of Rhine from other populations.

The highest length of simple hair in stem $(107.14 \mu \mathrm{m})$ was observed in Niroogah population, while Evan population had the highest value of thickness of epidermis (29.14 $\mu \mathrm{m})$ and upper phloem $(55.18 \mu \mathrm{m})$. The lowest thickness of pith $(539.68 \mu \mathrm{m})$ and xylem $(101.46 \mu \mathrm{m})$ in stem was observed in Niroogah.

All the leaves in the sections were bifacial (dorsiventral and amphistomatic mesophyll) type and were com-

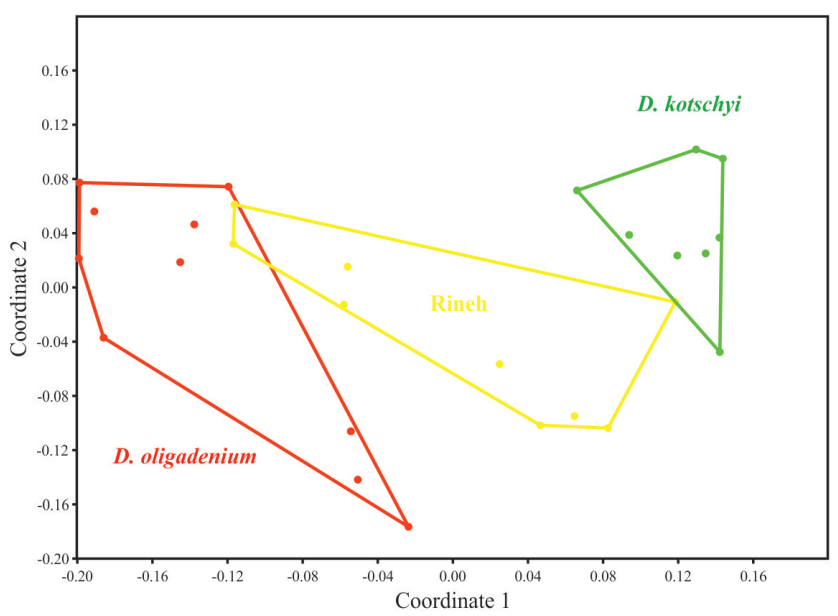

Figure 4. PCOA plot of species based on ISSR. 
Table 6. Anatomical traits in the studied populations.

\begin{tabular}{|c|c|c|c|c|c|c|c|}
\hline \multirow[b]{2}{*}{ Characters } & \multicolumn{7}{|c|}{ Populations } \\
\hline & Rineh & Fasham & Evan & Noor & Namarestagh & Niroogah & Roodbar \\
\hline Thickness of parenchyma in stem $(\mu \mathrm{m})$ & 68.81 & 50.99 & 60.61 & 49.16 & 63.44 & 61.54 & 43.52 \\
\hline Thickness of sclerenchyma in stem $(\mu \mathrm{m})$ & 33.44 & 15.45 & 30.37 & 20 & 26.34 & 16.66 & 16.66 \\
\hline Thickness of upper phloem in stem $(\mu \mathrm{m})$ & 39.69 & 28.36 & 55.18 & 35.8 & 38.86 & 46.16 & 30.37 \\
\hline Thickness of xylem in stem $(\mu \mathrm{m})$ & 146.41 & 152.05 & 157.79 & 165.86 & 162.46 & 101.46 & 214.76 \\
\hline Thickness of lower phloem in stem $(\mu \mathrm{m})$ & 62.4 & 42.81 & 46.86 & 53.68 & 52.68 & 49.16 & 46.86 \\
\hline Thickness of pith in stem $(\mu \mathrm{m})$ & 648.36 & 610.29 & 627.69 & 707.93 & 770.06 & 539.68 & 709.54 \\
\hline Length of transects in stem $(\mu \mathrm{m})$ & 1125.63 & 1111.99 & 1125.93 & 1102 & 1265.73 & 1070.68 & 1291.96 \\
\hline Width of transects in stem $(\mu \mathrm{m})$ & 1035.69 & 1003.26 & 1178.92 & 1154.89 & 1307.87 & 969.01 & 1265.76 \\
\hline Length of simple hair in stem $(\mu \mathrm{m})$ & 76.08 & 55.48 & 83.3 & 77.72 & 81.72 & 107.14 & 56.57 \\
\hline Length of glandular hair in stem $(\mu \mathrm{m})$ & 46.51 & 25.87 & 22.31 & 25.56 & 26.34 & 15.45 & 34.52 \\
\hline Number of layers of collenchymas in stem & 8 & 8 & 11 & 8 & 11 & 9 & 10 \\
\hline Number of layers of parenchyma in stem & 3 & 3 & 4 & 4 & 4 & 5 & 3 \\
\hline Number of layers of xylem in stem $(\mu \mathrm{m})$ & 12 & 16 & 20 & 19 & 20 & 19 & 18 \\
\hline Thickness of upper epidermis in leaf $(\mu \mathrm{m})$ & 38.33 & 35.25 & 57.14 & 87.41 & 51.11 & 40.41 & 74.51 \\
\hline Thickness of collenchymas in leaf $(\mu \mathrm{m})$ & 113.43 & 111.23 & 127.78 & 166.6 & 126.49 & 133.4 & 153.76 \\
\hline Thickness of parenchyma in leaf $(\mu \mathrm{m})$ & 234.49 & 140.23 & 143.88 & 193.36 & 247.9 & 225.41 & 179.34 \\
\hline Thickness of upper phloem in leaf $(\mu \mathrm{m})$ & 73.18 & 70.32 & 137.14 & 118.91 & 130.31 & 101.1 & 157.64 \\
\hline Thickness of xylem in leaf $(\mu \mathrm{m})$ & 185.87 & 157.23 & 208.55 & 199.92 & 206.51 & 159.18 & 165.71 \\
\hline Thickness of simple hair in leaf $(\mu \mathrm{m})$ & 174.07 & 126.32 & 154.39 & 225.12 & 131.55 & 243.31 & 142.97 \\
\hline Thickness of glandular hair in leaf $(\mu \mathrm{m})$ & 66.64 & 57.23 & 77.72 & 59.66 & 63.89 & 105.37 & 65.15 \\
\hline Number of layers of collenchymas in leaf & 3 & 2 & 2 & 2 & 3 & 3 & 2 \\
\hline Number of layers of parenchyma in leaf & 4 & 4 & 4 & 5 & 5 & 5 & 4 \\
\hline Number of layers of xylem in leaf & 8 & 5 & 6 & 8 & 7 & 5 & 6 \\
\hline Thickness of lower phloem in leaf $(\mu \mathrm{m})$ & 174.07 & 126.32 & 154.39 & 225.12 & 131.55 & 243.31 & 142.97 \\
\hline
\end{tabular}

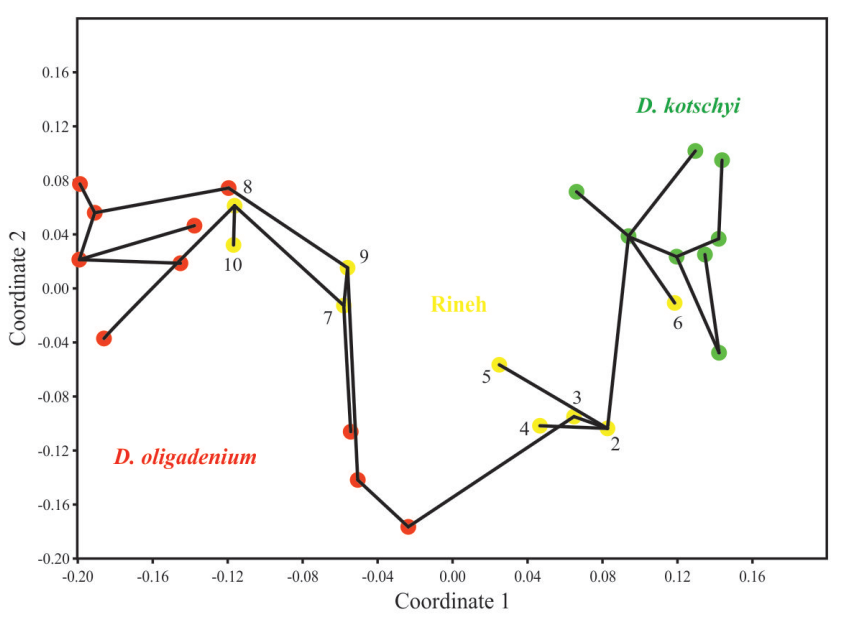

Figure 5. MST plot of species based on ISSR.

posed of one-layered epidermis. The highest thickness of the lower phloem $(243.32 \mu \mathrm{m})$, simple $(233.31 \mu \mathrm{m})$ and glandular $(105.37 \mu \mathrm{m})$ hair in leaf was observed in Niroogah population and the highest thickness of the upper epidermis $(87.41 \mu \mathrm{m})$ and collenchyma $(166.6 \mu \mathrm{m})$ in leaf was observed in Noor population. The lowest thickness of epidermis $(35.25 \mu \mathrm{m})$, collenchyma (111.23 $\mu \mathrm{m})$, parenchyma $(140.23 \mu \mathrm{m})$, xylem $(157.23 \mu \mathrm{m})$, lower and upper phloem (70.32 and $126.32 \mu \mathrm{m}$, respectively), and length of glandular and simple hair (126.32 and 57.23 $\mu \mathrm{m}$, respectively) in leaf was observed in Niroogah.

\section{ISSR study}

For ISSR studies, representatives of D. oligadenium and $D$. kotschyi as well as population of Rhine were analysed. PCA plot of ISSR data (Fig. 4), followed by minimum spanning tree (MST), separated D. oligadenium and D. kotschyi species from each other, while Rineh population was placed in an intermediate position. The MST plot revealed that some plants were genetically closer to $D$. oligadenium (plants 7, 8, 9 and 10 in Fig. 5); while some others were closer to D. kotschyi (plants 2, 3, 4, 5 and 6 in Fig. 5). This agrees with the results of the morphological and anatomical investigations.

\section{Discussion}

Species differentiation is an important taxonomic task which can be achieved through a combination of various characteristics and approaches (Sheidai et al. 2014). We could differentiate two species of $D$. oligadenium and $D$. kotschyi by using a combination of morphological, anatomical as well as molecular data. Taxonomic recognition of 
these two species has been also done previously by using pollen data (Naderifar et al. 2015).

The present study also discovered hybrid plants between these two species. Natural hybridization is a widespread phenomenon in plant species and occurs in $40 \%$ of vascular plant families. The frequency of natural hybridization in plants varies among families, genera, and species pairs.

Interspecific hybridization is an important evolutionary mechanism that brings about two genomes of divergent but related species together. It can produce new genetic and phenotypic traits that can help the species ecological adaptation (Freeland et al. 2011). Interspecific hybridization occurs frequently in various plants groups but is under influence of different factors like, the genetic architecture of the species involved, the fitness of the hybrid and genotype-environment interaction (Freeland et al. 2011).

Natural interspecific hybridization occurs with high frequency in Lamiaceae family (see e.g., Gobert et al. 2002; Idowu and Oziegbe 2017; Mamadalieva et al. 2017).

The hybridization can lead to a large diversity in different characters; for example, in Tamarix, different species can interbreed naturally and form different hybrids with extensive range of morphological variation, depending on the degree of introgression and genetic contribution of the parental species (Ijbari et al. 2014). In case of Helichrysum, the hybrid plants were formed between Helichrysum armenium and Helichrysum rubicundum and showed intermediate morphological characters (Taban et al. 2015). The hybrids were formed in the hybrid zone, where the two species overlapped. The same is true in our present investigation as we collected hybrid plants in the overlapping area between $D$. oligadenium and $D$. kotschyi.

Usually, the hybrids are identified based on intermediate morphological and molecular characteristics. The same holds true for Dracocephalum "hybrid plants" as they were placed between the two parental taxa in MDS plot of ISSR data. Moreover, they showed intermediate anatomical features too. To our knowledge, this is the first report on the occurrence of a natural interspecific hybrid in the genus Dracocephalum

\section{References}

Brach AR, Song H (2006) eFloras: New directions for online floras exemplified by the Flora of China Project. Taxon 55(1):188-192.

Budantsev AL (1987) The system of the genus Dracocephalum (Lamiaceae). Bot Zh 72:260-267.

Budantsev AL (1993) A synopsis of the tribe Nepeteae (Lamiaceae) the genera Lophanthus, Dracocephalum, Cedronella,
Schizonepeta and Agastache. Bot Zh 78:106-115.

Esfandiari E (1985) Dracocephalum oligadenium (Labiatae), a distinct species. Iran J Bot 3:75-76.

Freeland JR, Kirk H, Peterson SD (2011) Molecular Ecology. $2^{\text {nd }}$ ed., Wiley-Blackwell, UK.

Gobert V, Moja S, Colson M, Taberlet P (2002) Hybridization in the section Mentha (Lamiaceae) inferred from AFLP markers. Am J Bot 89:2017-2023.

Hammer Ø, Harper DAT, Ryan, P. D (2012) PAST: Paleontological statistics software package for education and data analysis. Palaeontol Electron 4:9.

Huson DH, Bryant D (2006) Application of phylogenetic networks in evolutionary studies. Mol Biol Evol 23:254-267.

Idowu JA, Oziegbe M (2017) Mitotic and meiotic studies on two species of Ocimum (Lamiaceae) and their $\mathrm{F}_{1}$ hybrids. Bot Lith 23(1):59-67.

Ijbari H, Sheidai M, Mehrabian AR, Noormohammadi Z, Ghasemzadeh-Baraki S (2014) K-means clustering and STRUCTURE analyses of genetic diversity in Tamarix L. accessions. Turk J Bot 38(6):1080-1094.

Jahaniani F, Ebrahimi SA, Rahbar-Roshandel N, Mahmoudian M (2005) Xanthomicrol is the main cytotoxic component of Dracocephalum kotschyi and a potential anticancer agent. Phytochemistry 66:1581-1592.

Jamzad Z (2012) Dracocephalum L. In Assadi M, Maassoumi AA, Mozaffarian M, ed., Flora of Iran. Research Institute of Forests and Rangelands Press, Tehran, Iran. 424-444.

Jensen WA (1962) Botanical Histochemistry - Principles and Practice, $1^{\text {st }}$ ed., Freeman, William and Jensen, San Francisco, California.

Kadereit JW (2004) Flowering Plants: Dicotyledons, Lamiales (except Acanthaceae including Avicenniaceae). In Kubitzki K, ed., The Families and Genera of Vascular Plants. Springer Verlag, Berlin.

Mamadalieva NZ, Sharopov F, Satyal P, Azimova SS, Wink M (2017) Composition of the essential oils of three Uzbek Scutellaria species (Lamiaceae) and their antioxidant activities. Nat Prod Res 31:1172-1176.

Naderifar M, Sonboli A, Gholipou A (2015) Pollen morphology of Iranian Dracocephalum L. (Lamiaceae) and its taxonomic significance. Bangladesh J Plant Taxon 22:99-110.

Podani J (2000) Introduction to the Exploration of Multivariate Data. Backhuys Publishers, Leiden, The Netherlands.

Rechinger KH (1982) Dracocephalum. In Rechinger KH, ed., Flora Iranica. Akademische Druck-U: Verlagsanstalt, Graz, Austria. 218-230.

Sajjadi SE, MovahedianV, Attar, Yektaeian A (1998) Antihyperlipidemic effect of hydroalcoholic extract, and polyphenolic fraction from Dracocephalum kotschyi Boiss. Pharm Acta Helv 73:167-170.

Sheidai M, Afshar F, Keshavarzi M, Talebi SM, Noormohammadi Z, Shafaf T (2014) Genetic diversity and genome size 
variability in Linum austriacum (Lineaceae) populations. Biochem Syst Ecol 57:20-26.

Sonboli A, Mojarrad M, Gholipour A, Nejad Ebrahimi S, Arman M (2008) Biological activity and composition of the essential oil of Dracocephalum moldavica L. grown in Iran. Nat Prod Commun 3:1547-1550.

Sonboli A, Gholipour A, Mirjalili MH, Amini Rad M (2011) Molecular characterization of Iranian Dracocephalum (Lamiaceae) species based on RAPD data. Acta Biol Szeged 55:227-230.
Taban M, Sheidai M, Noormohammadi Z, Azizi N, Ghasemzadeh-Barak S, Koohdar F (2015) Population genetic analysis and evidence of inter-specific introgression in Helichrysum armenium and $H$. rubicundum (Asteraceae). Genetika 47:451-468.

Zeng Q, Jin HZ, Qin JJ, Fu JJ, Hu HJ, Li J H, Yan L, Chen M, Zhang DW (2010) Chemical constituents of plants from the genus Dracocephalum. Chem Biodivers 7:1911-1929. 
